\title{
Fomites in the Fitness Center: Fitness Equipment Harbors Antibiotic Resistant and Pathogenic Bacteria
}

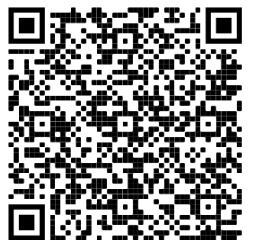

\author{
Pierce Prevost ${ }^{1}$ and Dawn Simms ${ }^{1 *}$
}

Infections may spread indirectly when an infected person touches an object (i.e., fomite) leaving behind a pathogen that is picked up by the next person to touch that object. Fitness centers offer a unique opportunity for investigating fomite transmission of pathogenic bacteria, because these facilities are used by persons with varying levels of personal hygiene routinely sharing equipment via frequent and direct surface-to-skin contact. Previous studies of this phenomenon have investigated too few species, and/or failed to differentiate pathogenic or antibiotic resistant bacteria from non-pathogenic or antibiotic susceptible bacteria. The aims of this study were to survey fitness equipment for the presence of World Health Organization (WHO) priority pathogens and to test the hypothesis that fitness equipment are hosts to an abundance of pathogenic and antibiotic resistant bacteria. Swab samples were taken at three local fitness centers from equipment used in a typical workout routine which require direct surface-to-skin contact for proper use (i.e., barbells, chest fly machines, and dumbbells). Bacterial load, presence of pathogenic bacteria, and abundance of pathogenic and antibiotic resistant strains was determined via serial dilutions and plate counts, selective screening with specialized growth media, colony isolation, and biochemical tests using API ${ }^{\circledR}$ 20E chemical panels (bioMerieux, VWRTM, Radnor, PA), respectively. The most notable results of this study were bacterial loads much higher than what has been found in previous studies (Goldhammer et al., 2006; Ryan et al., 2011; Mukherjee et al., 2014; Ibrahim et al., 2018; Dalman et al., 2019; Fadare, 2019) and 100 percent of fomites testing positive for Methicillin-resistant Staphylococcus aureus (MRSA).

\section{INTRODUCTION}

According to the International Health, Racquet and Sports Club Association (IHRSA), there were over six billion visits to 39,570 gyms and fitness centers in 2018 (Rodriguez, 2019). Due in part to this high level of patronage, these facilities are known to be potential reservoirs for community infections (Mukherjee et al., 2014). The nature of many workout routines (i.e., alternation between muscle groups and, therefore, between several types of equipment), combined with the fact that these equipment are shared by a large number of patrons, results in an environment suitable for indirect

Address correspondance to:

'Franciscan Missionaries of Our Lady University,

5414 Brittany Drive, Baton Rouge, LA 70808

*dawn.simms@franu.edu

doi:10.22186/jyi.39.2.16-21

Submission date: October 2019

Acceptance date: June 2020

Publication date: February 2021 fomite (e.g., inanimate object) transmission of pathogens. Fomite transmission in a fitness center may occur, for example, when an infected person uses a piece of fitness equipment, sheds pathogenic bacterial cells onto said equipment, subsequently neglects to properly clean the equipment after use, and then leaves the pathogenic equipment for other individuals to utilize. This mode of pathogen transmission is possible, because many microorganisms can survive for long periods of time on fomites. For example, Methicillinresistant Staphylococcus aureus (MRSA) has been shown to survive on inanimate surfaces for up to 60 days (Williams and Davis, 2009).

Community-acquired MRSA infections are known to be quite common (Tacconelli et al., 2018), and several studies have identified public gyms and fitness centers as possible sources of community infections (Goldhammer et al., 2006; Ryan et al., 2011; Mukherjee et al., 2014; Ibrahim et al., 2018; Dalman et al., 2019; Fadare, 2019). However, results of these studies are often conflicted or limited. For example, one study found MRSA and methicillin-susceptible Staphylococcus aureus (MSSA) on 98\% of equipment sampled (Mukhurjee et al., 2014), while another study found no trace of MRSA on fitness equipment in three community gyms (Ryan et al., 2011). However, another study (Goldhammer et al., 2006) found no pathogens (MRSA or otherwise) on any fitness equipment, even in samples taken prior to equipment 
disinfection. Indeed, many studies focus on a limited subset of bacterial species or neglect to account for strains resistant to antibiotics, a pertinent area of research.

Several species of bacteria are increasingly becoming resistant to antibiotics, which means a larger proportion of pathogenic bacteria are becoming especially difficult to treat. According to the World Health Organization (WHO), approximately two million people are infected with antibiotic resistant pathogens (resulting in over 23,000 deaths) per year (Ibrahim et al., 2018). WHO priority pathogens (pathogens which are deemed to be urgently requiring more research due to their transmissibility and mortality rates, among other factors (Table 1) include antibiotic resistant Acinetobacter baumannii, Pseudomonas aeruginosa, Enterococcus faecium, Helicobacter pylori, Neisseria gonorrhoeae, Salmonella typhi, and several Enterobacteriaceae and Campylobacter species, in addition to MRSA (Tacconelli et al., 2018). Not enough is known about the quantity and diversity of these and other bacteria in fitness centers (Ibrahim et al., 2018).

These factors taken together (i.e., the high level of patronage in fitness centers combined with the commonality of community-acquired bacterial infections, the increase in antibiotic-resistant bacteria, and the dearth of research regarding $\mathrm{WHO}$ pathogens in fitness centers) illustrate the need for more research in this field. This study aimed to evaluate the role of fitness centers as community reservoirs for pathogenic and/or antibiotic resistant bacteria by testing the hypothesis that fitness center equipment are host to an abundance of WHO priority pathogens (Table 1). The expectation was to expand upon the limited knowledge of the potential for fitness centers to become reservoirs for community infection.

\section{METHODS}

\section{Sample Collection}

Barbells, chest fly machines, and dumbbells were sampled from three local fitness centers which ranged in size from 3,500 to 16,000 square feet. These equipment were chosen for investigation, because they 1) were available for use at all three fitness centers, 2) are widely used as part of a typical workout routine (Hyde and Geiger, 2018), and 3) require direct surface-to-skin contact (via hands) to operate, making them potential fomites (i.e., reservoirs for pathogenic bacteria). Samples were taken at the same time of day ( 5:00 $\mathrm{pm})$ at each fitness center to reduce site-to-site variability. Sampled equipment were swabbed in triplicate using sterile cotton-tipped applicators (Med Vet International, Fisher ScientificTM, Waltham, MA) and latex gloves. The swabs were immediately placed in $5 \mathrm{~mL}$ of sterile deionized water and then stored at $4{ }^{\circ} \mathrm{C}$ until they could be processed in the laboratory.

\section{Culturing Conditions}

Each swab sample was used to prepare stock broth cultures in order to cultivate an adequate quantity of bacteria to be used for further testing. Stock broth cultures consisted of 5
Table 1. Identifying Characteristics of WHO Priority Pathogens. Fitness equipment was surveyed for the presence of World Health Organization (WHO) priority pathogens, which are pathogens which are deemed to be urgently requiring more research due to their mortality rates, among other factors. Some identifying characteristics for these pathogens include classification, Gram reaction, cell morphology, and aerotolerance.

\begin{tabular}{|lllll|}
\hline Name & $\begin{array}{l}\text { Classifi- } \\
\text { cation }\end{array}$ & $\begin{array}{l}\text { Gram } \\
\text { Reaction }\end{array}$ & $\begin{array}{l}\text { Cell } \\
\text { Morphology }\end{array}$ & Aerotolerance \\
\hline $\begin{array}{l}\text { Acinetobacter } \\
\text { baumannii }\end{array}$ & species & negative & bacillus & $\begin{array}{l}\text { obligate } \\
\text { aerobe }\end{array}$ \\
$\begin{array}{l}\text { Pseudomonas } \\
\text { aeruginosa }\end{array}$ & species & negative & bacillus & $\begin{array}{l}\text { facultative } \\
\text { aerobe }\end{array}$ \\
$\begin{array}{l}\text { Enterococcus } \\
\text { faecium }\end{array}$ & species & positive & cocci & $\begin{array}{l}\text { microaero- } \\
\text { philic }\end{array}$ \\
$\begin{array}{l}\text { Helicobacter } \\
\text { pylori }\end{array}$ & species & negative & spirochetes & $\begin{array}{l}\text { aerotolerant } \\
\text { capnophilic } \\
\text { anaerobe }\end{array}$ \\
$\begin{array}{l}\text { Neisseria gonor- } \\
\text { rheae }\end{array}$ & species & negative & diplococci & $\begin{array}{l}\text { obligate } \\
\text { aerobe }\end{array}$ \\
$\begin{array}{l}\text { Salmonella typhi } i \\
\text { species }\end{array}$ & negative & bacillus & $\begin{array}{l}\text { facultative } \\
\text { anaerobe }\end{array}$ \\
$\begin{array}{l}\text { Enterobactera- } \\
\text { ceae }\end{array}$ & family & negative & bacillus & $\begin{array}{l}\text { facultative } \\
\text { anaerobe }\end{array}$ \\
Campylobacter & genus & negative & $\begin{array}{l}\text { spirochetes/ } \\
\text { bacillus }\end{array}$ & $\begin{array}{l}\text { obligate } \\
\text { anaerobe }\end{array}$ \\
MRSA & species & positive & $\begin{array}{l}\text { staphylococ- } \\
\text { cus }\end{array}$ & $\begin{array}{l}\text { facultative } \\
\text { anaerobes }\end{array}$ \\
\hline
\end{tabular}

$\mathrm{mL}$ of Tryptic soy broth (TSB) inoculated with $1 \mathrm{~mL}$ of stored swab sample. TSB was prepared by mixing $12 \mathrm{~g}$ of the commercially available powder (RemelTM, Fisher ScientificTM, Waltham, MA) with $400 \mathrm{~mL}$ of deionized water. This mixture was sterilized via autoclave (at $121^{\circ} \mathrm{C}$ for 25 minutes) and then allowed to cool to room temperature prior to inoculation. Inoculated broth cultures were incubated at $37^{\circ} \mathrm{C}$ for 24 hours and then stored at $4^{\circ} \mathrm{C}$ for further processing.

\section{Bacterial Loads}

To quantify the bacterial loads for each swab sample, ten-fold serial dilutions were performed, followed by plate counts. Each sample to be enumerated was first prepared from $1 \mathrm{~mL}$ of stock broth culture mixed with $9 \mathrm{~mL}$ of sterile TSB. Next, $100 \mu \mathrm{L}$ of each sample was mixed with $900 \mu \mathrm{L}$ of sterile deionized water. Then, $100 \mu \mathrm{L}$ of this mixture was mixed with $900 \mu \mathrm{L}$ of sterile deionized water. This process was repeated until dilution factors for each sample ranged from $10^{-1}$ to $10^{-10}$. Diluted samples were next used to create countable plates, i.e., plates containing between 30 and 300 bacterial colonies. The spread plate method (even distribution of sample on agar surface via plate spreader) was employed to enumerate bacterial loads for the more highly 


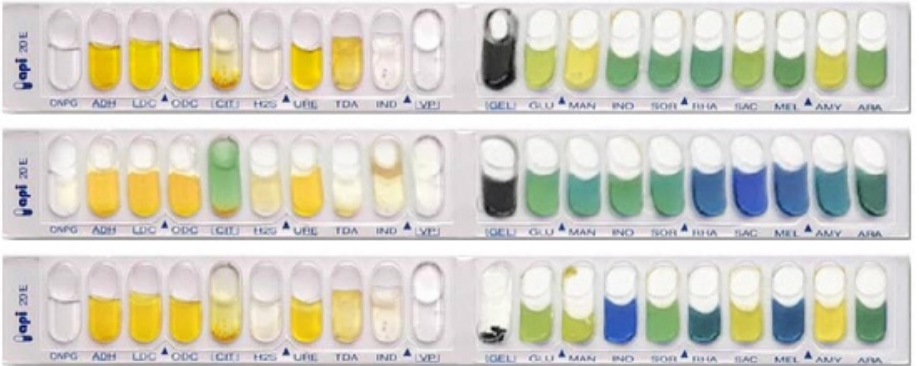

Figure 1. $\mathrm{API}^{\circledR} 20 \mathrm{E}$ Test Panels. $\mathrm{API}^{\circledR} 20 \mathrm{E}$ test panels were used to further identify specimen which showed positive results for screening via Gram-negative selective media. These panels included a series of 20 biochemical tests; the results of which were then cross referenced with the Analytical Profile Index (APIWEBTM), Bergey's Manual of Determinative Microbiology (Holt, 1994), and D-Bite Database (B. M. Birla Science and Technology Centre, 2016) to confirm identification on genus and/or species level(s).

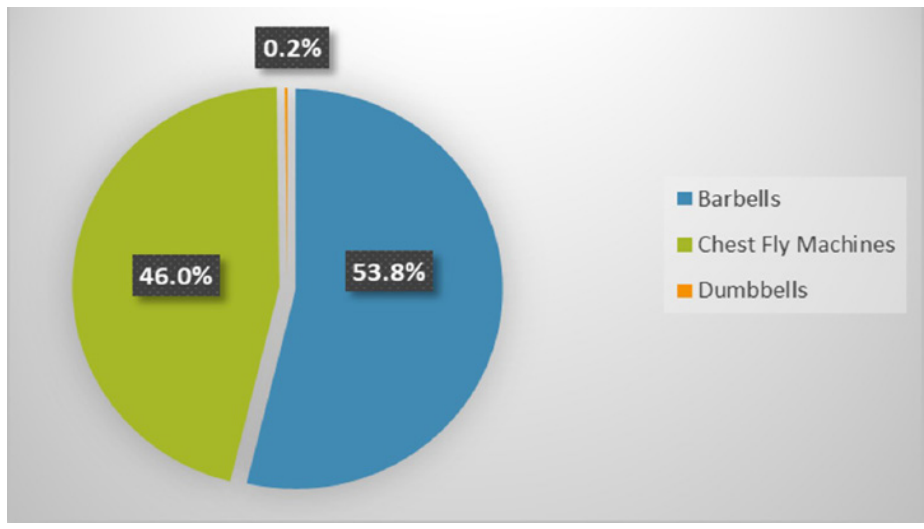

Figure 2. Bacterial Load Distribution by Equipment Type. A comparison of combined bacterial loads among the three types of fitness equipment investigated: barbells had the highest combined bacterial load $\left(1.2 \times 10^{13} \mathrm{CFU} / \mathrm{mL}\right)$, followed closely by chest fly machines $\left(1.0 \times 10^{13} \mathrm{CFU} / \mathrm{mL}\right)$. There were much less bacteria $\left(4.5 \times 10^{10} \mathrm{CFU} / \mathrm{mL}\right)$ found on dumbbells, significantly less than on barbells $(F=502.95, p<0.001)$ or on chest fly machines $(F=$ 541.96, $p<.001)$.

diluted samples (i.e., dilution factors of $10^{-7}, 10^{-8}, 10^{-9}$, and $10^{-10}$ ), which increased the chances of producing countable plates.

Agar plates were prepared with nutrient agar (NA) by mixing $9.2 \mathrm{~g}$ of commercially available NA powder (RemelTM, Fisher ScientificTM, Waltham, MA) with $400 \mathrm{~mL}$ deionized water. This mixture was sterilized via autoclave (at $121^{\circ} \mathrm{C}$ for 25 minutes), then poured (13 $\mathrm{mL}$ each) into $150 \mathrm{~mm}$ Petri dishes (Fisherbrand ${ }^{\mathrm{TM}}$, Fisher Scientific ${ }^{\mathrm{TM}}$, Waltham, MA), and finally allowed to cool to room temperature prior to inoculation. Post inoculation, the dilution plates were incubated at $37^{\circ} \mathrm{C}$ for 24 hours.

After incubation, colony-forming units per milliliter (CFU/ $\mathrm{mL}$ ) were calculated for each countable plate. This is the conventional way of reporting bacterial loads and represents the number of bacterial cells found in $1 \mathrm{~mL}$ of an experimental sample. It is calculated by multiplying the number of colonies present on the countable plate by the reciprocal of the dilution factor used to inoculate said plate.

\section{Selective Screening}

Preliminary screening for WHO priority pathogens was performed using selective and specialized media plates, each inoculated via simple streak method and incubated at $37^{\circ} \mathrm{C}$ for 24 hours. Selective screening for Gram-negative pathogens (e.g., P. aeruginosa, H. pylori, and S. typhi) (Table 1), was done by observing growth characteristics and morphologies for each broth culture on MacConkey agar (RemelTM, Fisher Scientific ${ }^{\mathrm{TM}}$, Waltham, MA). MacConkey agar plates were prepared by mixing 20 grams of the commercial powder with $400 \mathrm{~mL}$ deionized water. This mixture was sterilized via autoclave (at $121^{\circ} \mathrm{C}$ for 25 minutes), poured (13 mL each) into $150 \mathrm{~mm}$ Petri dishes (Fisherbrand ${ }^{\mathrm{TM}}$, Fisher Scientific $^{\mathrm{TM}}$, Waltham, MA), and then allowed to cool to room temperature prior to inoculation. Further screening for fluoroquinolone-resistant Salmonella was performed using premade specialty media, i.e., MacConkey agar plates with 1 $\mu \mathrm{g} / \mathrm{mL}$ ciprofloxacin (Remel $^{\mathrm{TM}}$, Fisher Scientific ${ }^{\mathrm{TM}}$, Waltham, $M A)$.

Selective screening for MRSA was done by observing growth characteristics and morphologies for each broth culture on premade Thermo ScientificTM SpectraTM MRSA medium (Fisher ScientificTM, Waltham, MA). Additional screening for Vancomycin-resistant E. faecium was performed using Thermo ScientificTM RemelTM Columbia CNA $\mathrm{w} / 5 \%$ Sheep Blood and Vancomycin $(6 \mu \mathrm{g} / \mathrm{mL}$; Fisher ScientificTM, Waltham, MA).

\section{Analytical Profile Index}

Identification was confirmed and refined for suspected Gram-negative pathogens by performing $\mathrm{API}^{\circledR}$ 20E chemical panels (bioMerieux, VWRTM, Radnor, PA) on colonies successfully isolated on MacConkey agar and by comparing the results to those listed in the analytical profile index (APIWEBTM). These chemical panels allowed for fast, accurate identification of Enterobacteriaceae family bacteria to the genus- or species-level. Samples taken from isolated colonies were suspended in $1 \mathrm{~mL}$ of TSB and pipetted into each of the 20 wells of the panel. The panels were then incubated overnight at $37^{\circ} \mathrm{C}$, and observed for byproducts of specific biochemical reactions (Figure 1). Results of these reactions were compared to those listed in the analytical profile index (APIWEBTM) and crossed-referenced with Bergey's Manual of Determinative Microbiology (Holt, 1994) and D-Bite Database (B. M. Birla Science and Technology Centre, 2016) for further confirmation of genus and/or species identification. 
Table 2. Overall Results Summary. Summarized results for all tests are shown, including bacterial loads, selective screening, and analytical profile index. The single highest bacterial load $\left(1.0 \times 10^{13} \mathrm{CFU} / \mathrm{mL}\right)$ was found on one set of barbells, while the lowest bacterial load $\left(7.6 \times 10^{9} \mathrm{CFU} / \mathrm{mL}\right)$ was found on one of the three chest fly machines. Employing several types of selective media and API $20 \mathrm{E}$ test panels, several pathogens where identified, including MRSA, vancomycin-resistant Enterococcus faecium, fluoroquinolone-resistant Salmonella, and Edwardsiella tarda.

\begin{tabular}{|c|c|c|c|c|c|c|c|c|c|}
\hline \multirow{2}{*}{ Equipment and Location } & \multicolumn{3}{|c|}{ Barbells } & \multicolumn{3}{|c|}{ Chest Fly Machines } & \multicolumn{3}{|c|}{ Dumbbells } \\
\hline & 1 & 2 & 3 & 1 & 2 & 3 & 1 & 2 & 3 \\
\hline Bacterial Load: CFU/mL & $2.2 \mathrm{E}+10$ & $2.1 \mathrm{E}+12$ & $1.0 \mathrm{E}+13$ & $1.0 \mathrm{E}+13$ & $7.6 \mathrm{E}+09$ & $3.5 \mathrm{E}+11$ & $8.3 \mathrm{E}+09$ & $2.7 \mathrm{E}+10$ & $9.5 \mathrm{E}+0.9$ \\
\hline MacConkey Agar & No growth & $\begin{array}{l}\text { Growth }(+) \\
\text { Color } \\
\text { change }(+)\end{array}$ & No growth & No growth & $\begin{array}{l}\text { Growth }(+) \\
\text { Color } \\
\text { change }(+)\end{array}$ & $\begin{array}{l}\text { Growth }(+) \\
\text { Color } \\
\text { change (-) }\end{array}$ & No growth & $\begin{array}{l}\text { Growth }(+) \\
\text { Color } \\
\text { change }(-)\end{array}$ & $\begin{array}{l}\text { Growth }(+) \\
\text { Color } \\
\text { change }(+)\end{array}$ \\
\hline $\begin{array}{l}\text { MacConkey Agar w/ 1\% } \\
\text { ciprofloxacin }\end{array}$ & No growth & No growth & No growth & No growth & $\begin{array}{c}\text { Growth }(+) \\
\text { resistant }\end{array}$ & No growth & $\begin{array}{l}\text { Growth }(+) \\
\text { resistant }\end{array}$ & No growth & No growth \\
\hline $\begin{array}{l}\text { Spectra }^{\mathrm{TM}} \text { MRSA } \\
\text { Medium }\end{array}$ & $\begin{array}{l}\text { Growth }(+) \\
\text { Color } \\
\text { change }(+)\end{array}$ & $\begin{array}{l}\text { Growth }(+) \\
\text { Color } \\
\text { change }(+)\end{array}$ & $\begin{array}{l}\text { Growth }(+) \\
\text { Color } \\
\text { change }(+)\end{array}$ & $\begin{array}{l}\text { Growth }(+) \\
\text { Color } \\
\text { change }(+)\end{array}$ & $\begin{array}{l}\text { Growth }(+) \\
\text { Color } \\
\text { change }(+)\end{array}$ & $\begin{array}{l}\text { Growth }(+) \\
\text { Color } \\
\text { change }(+)\end{array}$ & $\begin{array}{l}\text { Growth }(+) \\
\text { Color } \\
\text { change }(+)\end{array}$ & $\begin{array}{l}\text { Growth }(+) \\
\text { Color } \\
\text { change }(+)\end{array}$ & $\begin{array}{l}\text { Growth }(+) \\
\text { Color } \\
\text { change }(+)\end{array}$ \\
\hline $\begin{array}{l}\text { Columbia CNA w/ } 5 \% \\
\text { sheep blood and vanco- } \\
\text { mycin }\end{array}$ & No growth & $\begin{array}{c}\text { Growth }(+) \\
\text { resistant }\end{array}$ & No growth & No growth & $\begin{array}{c}\text { Growth }(+) \\
\text { resistant }\end{array}$ & $\begin{array}{l}\text { Growth }(+) \\
\text { resistant }\end{array}$ & $\begin{array}{l}\text { Growth }(+) \\
\text { resistant }\end{array}$ & No growth & No growth \\
\hline API $20 \mathrm{E}$ test panels & NA & $\begin{array}{l}\text { Salmonella, } \\
\text { Edwardsi- } \\
\text { ella tarda }\end{array}$ & NA & NA & $\begin{array}{l}\text { Salmonella, } \\
\text { Edwardsi- } \\
\text { ella tarda }\end{array}$ & $\begin{array}{c}\text { Salmonella } \\
\text { typhi }\end{array}$ & Salmonella & $\begin{array}{l}\text { Edwardsi- } \\
\text { ella tarda }\end{array}$ & Salmonella \\
\hline Genus/species identified & MRSA & $\begin{array}{l}\text { MRSA, } \\
\text { vancomycin- } \\
\text { resistant } \\
\text { Enterococ- } \\
\text { cus faecium, } \\
\text { Salmonella, } \\
\text { Edwardsi- } \\
\text { ella tarda }\end{array}$ & MRSA & MRSA & $\begin{array}{l}\text { fluoroqui- } \\
\text { nolone- } \\
\text { resistant } \\
\text { Salmonella } \\
\text { MRSA, } \\
\text { vancomycin- } \\
\text { resistant } \\
\text { Enterococ- } \\
\text { cus faecium, } \\
\text { Edwardsi- } \\
\text { ella tarda }\end{array}$ & $\begin{array}{l}\text { MRSA, } \\
\text { vancomycin- } \\
\text { resistant } \\
\text { Enterococ- } \\
\text { cus faecium, } \\
\text { Salmonella } \\
\text { typhi }\end{array}$ & $\begin{array}{l}\text { MRSA, fluo- } \\
\text { roquinolone- } \\
\text { resistant } \\
\text { Salmonella }\end{array}$ & $\begin{array}{l}\text { MRSA, Ed- } \\
\text { wardsiella } \\
\quad \text { tarda }\end{array}$ & $\begin{array}{l}\text { MRSA, } \\
\text { Salmonella }\end{array}$ \\
\hline
\end{tabular}

\section{RESULTS}

\section{Bacterial Loads}

Bacterial loads (CFU/mL) were quantified for each fitness equipment sampled at each fitness center (Table 2). The abundance of bacteria was such that even the lowest bacterial load was several billion cells and the highest was over ten trillion cells (range: $7.6 \times 10^{9}-1.0 \times 10^{13} \mathrm{CFU} / \mathrm{mL}$, mean: $2.5 \times 10^{12}, \sigma: 2.2 \times 10^{6} \mathrm{CFU} / \mathrm{mL}$ ). Analysis of variance (ANO$\mathrm{VA}$ ) tests showed there was no correlation between the size of each fitness center and bacterial load $(p>0.05)$. However, there was an effect of equipment type on bacterial load (Figure 2). For example, barbells had the highest combined bacterial load $\left(1.2 \times 10^{13} \mathrm{CFU} / \mathrm{mL}\right)$, followed closely by chest fly machines $\left(1.0 \times 10^{13} \mathrm{CFU} / \mathrm{mL}\right)$. There were much less bacteria $\left(4.5 \times 10^{10} \mathrm{CFU} / \mathrm{mL}\right)$ found on dumbbells, significantly less than on barbells $(F=502.95)$ or on chest fly machines $(F=541.96)$.

\section{Selective Screening}

Preliminary screening via MacConkey Agar yielded Gramnegative specimen on $56 \%$ of equipment sampled. Growth on MacConkey Agar indicated the presence of Gram-negative bacteria, and a change in color indicated the as yet to be identified bacterial species was capable of fermenting lactose. These specimens were chosen for further analysis (via $\mathrm{API}^{\odot} 20 \mathrm{E}$ test panels: bioMerieux, VWR ${ }^{\mathrm{TM}}$, Radnor, PA). Fluoroquinolone-resistant Salmonella screening resulted in positive results for $22 \%$ of equipment sampled (i.e., one chest fly machine and one dumbbell). SpectraTM MRSA agar yielded positive results for MRSA from all fitness equipment sampled. That is, MRSA was found on all three types of equipment sampled from all three fitness centers. Screening with Columbia CNA agar for Vancomycin-resistant $E$. faecium showed $55 \%$ of samples (including one barbell, two chest fly machines, and one dumbbell) were positive for antibiotic resistant $E$. faecium (Table 2).

\section{Overall Results}

Specimen obtained from swabbed barbells yielded $4.0 \mathrm{x}$ $10^{12}$ mean CFU $/ \mathrm{mL}$ of bacteria, of which, methicillin-resistant Staphylococcus aureus (MRSA), E. faecium (resistant), Salmonella (genus, susceptible), and E. tarda (susceptible) were successfully identified (Table 2). Chest fly machines were host to $3.5 \times 10^{12}$ mean CFU/mL of bacteria, consisting of MRSA, E. faecium (resistant), Salmonella (genus, resistant), S. typhi (resistant), and E. tarda (susceptible). 
Finally, dumbbells yielded $1.5 \times 10^{10}$ mean CFU $/ \mathrm{mL}$ of bacteria, including MRSA, Salmonella (genus, both resistant and susceptible), and E. tarda (susceptible). WHO priority pathogens not found in samples taken from any type of investigated fitness equipment included $A$. baumannii, $P$. aeruginosa, H. pylori, N. gonorrheae and Campylobacter (Table 1).

\section{DISCUSSION}

The results supported the hypothesis that fitness center equipment were host to an abundance of $\mathrm{WHO}$ priority pathogens. While previous studies reported fomite bacterial loads of up to 20 to 50 million CFU/mL (Chitturi and Lakshmi, 2018; Dalman, et al., 2019), this study yielded much a higher range $\left(7.6 \times 10^{9}-1.0 \times 10^{13} \mathrm{CFU} / \mathrm{mL}\right.$, mean: $2.5 \times 10^{12}$ $\mathrm{CFU} / \mathrm{mL}$ ) of bacterial abundance. Additionally, at least one (and up to three) antibiotic resistant WHO pathogens were identified from each equipment sampled (Table 2). MRSA was present in $100 \%$ of samples, which is of great concern, because this $\mathrm{WHO}$ pathogen is easily transmitted, highly symptomatic (sores that progress to infections of the heart and blood), and difficult to treat (Mayo Foundation, 2018). Fluoroquinolone-resistant Salmonella (present on 22\% of sampled equipment) causes fever, diarrhea, and abdominal pain (Mayo Foundation, 2018). S. enterica (serotype typhi) can present as gastroenteritis, typhoid-like illness, enteric fever (Bhetwal et al., 2017) and septicemia (Polat et al., 2017). Furthermore, positive screening for $E$. faecium is of concern, because these species can cause urinary tract infections, endocarditis, intra-abdominal infection (Bush and Perez, 2017), and are sometimes resistant to antibiotic treatment (Kristich et al., 2014) as seen in the results of this study. $E$. tarda, is part of the Enterobacteraceae family included in the WHO priority pathogen list (Tacconelli et al., 2018). E. tarda (found in $55 \%$ of samples) causes gastrointestinal disease with possible exacerbation of inflammatory bowel syndrome effects (Arya et al., 2011). Additionally, this species poses a threat of mortality to people with liver cirrhosis or liver disease (Hirai et al., 2015), although this is rare. In total, transference of these bacterial strains in recreational facilities is of great public health concern.

These findings expand upon the previously limited evaluation of fitness centers as bacterial reservoirs and give insight into the potential public health concerns of these facilities. There is a clear need for precaution when utilizing fitness center equipment, including widespread use of proper gym etiquette (i.e., wiping down equipment after use, sitting on towels, bringing mats from home) to help prevent the spread of potential pathogens (St. Clair Martin and Chaney, 2007). It is also important to shower and properly wash hands before and after an exercise routine, because these actions can greatly reduce the risk of infection and transmission of harmful bacteria (Mathur, 2011).
A surprising finding was the significantly lower abundance of bacteria found on the dumbbells as compared to barbells $(F=502.95)$ or on chest fly machines $(F=541.96)$. The types of material used in the construction of fitness equipment may be worthy of consideration in future studies. The standard for these equipment had been steel bars and plates since the founding of the International Foundation of Body Building (IFBB) in 1946. However, solely steel exposed and constructed equipment has given way to rubber coated equipment in recent years. For example, a recent study by Ibrahim et. al (2018) found that copper alloy weights and grips reduced bacterial loads by as much as $94 \%$, as compared to their rubber and stainless-steel counterparts.

Other studies have noted that there appears to be a lack of effective disinfection measures (Goldhammer et al., 2006) in gym facilities, and the present study results confirm this. A logical follow up study would be to assess antimicrobial activities of commercially available chemical disinfectants used to clean fitness center equipment, which is indeed, a study recently completed by the authors. It was found that a commercial disinfectant containing alkyl-dimethyl-ethyl benzyl and dimethyl-benzyl ammonium chlorides (namely, Formula $409^{\circledR}$ ) was able to kill all bacterial species on fitness equipment at a minimum inhibitory concentration (MIC) of $4.6 \mathrm{x}$ $10^{-2} \mu \mathrm{g} / \mathrm{mL}$, or $1 / 25$ its normal concentration (Prevost and Simms, 2020).

Further research may include larger sample sizes (i.e., more locations, greater variety of equipment, etc.) so as to increase the capacity for statistical analysis. Other studies may also aim to collect samples more longitudinally. For example, sampling for this study was done in the month of August, a time of the year when fitness center utilization may decrease due to vacationing and outdoor exercise options, among other factors.

It is also important to note that this study employed culture-dependent techniques and that many species of bacteria are difficult to culture (Vartoukian et. al, 2016). This means that even with extensive sampling and variable controls, diversity and abundance of pathogenic or antibiotic resistant bacteria on fitness center equipment may still be relatively unknown. Therefore, future experimental designs should include culture-independent (i.e., DNA sequencing and bioinformatics) methods.

\section{ACKNOWLEDGMENTS}

This study was funded by the Franciscan Missionaries of Our Lady University Sr. Edana Corcoran Professorship.

\section{REFERENCES}

Arya, A. V., Rostom, A., Dong, W. F., and Flynnd, A. N. (2011). Crohn's Disease Exacerbation Induced by Edwardsiella tarda Gastroenteritis. Case Reports in Gastroenterology, 5(3), 623-7. Available at: www.doi. org/10.1159/000334423.

Bhetwal, A., Maharjan, A., Khanal, P. R., and Parajuli, N. P. (2017). Enteric Fever Caused by Salmonella enterica Serovars with Reduced Sus- 
ceptibility of Fluoroquinolones at a Community Based Teaching Hospital of Nepal. International Journal of Microbiology, 1-6. Available at: www.doi.org/10.1155/2017/2869458.

B. M. Birla Science and Technology Centre (2016). D-Bite Database of Biochemical Tests of Pathogenic Enterobacteriaceae Family. BSIR Jaipur: 2015-16. Retrieved from: www.bioinfo.bisr.res.in/cgi-bin/project/ docter/index.cgi.

Bush, L. M. and Perez M. T. (2017). Merck Manual Enterococcal Infections. Retrieved from: www.merckmanuals.com/professional/infectious-diseases/gram-positive-cocci/enterococcal-infections.

Chitturi, C. M. and Lakshmi, P. J. (2018). Isolation, identification of bacteria associated with mobile phones and their antibiotic susceptibility. Indian Journal of Public Health Research and Development, 9 (9), 16-20. Available at: www.doi.org/ 10.5958/0976- 5506.2018.00961.0.

Dalman, M., Bhatta, S., Nagajothi, N., Thapaliya, D., Olson, H., Naimi, H. M., and Smith, T. C. (2019). Characterizing the molecular epidemiology of Staphylococcus aureus across and within fitness facility types. BMC Infectious Diseases, 19(1), 69. Available at: doi: 10.1186/ s12879-019-3699-7.

Fadare, O. S. and Durojaye, O. B. (2019). Antibiotic Susceptibility Profile of Bacteria Isolated from Fitness Machines in Selected Fitness Centers at Akure and Elizade University in Ondo State Nigeria. Microbiology Research Journal International, 26(6), 1-9. Available at: www.doi. org/10.9734/mrji/2018/v26i630084.

Goldhammer, K. A., Dooley, D. P., Ayala, E., Zera, W., and Hill, B. L. (2006), Prospective Study of Bacterial and Viral Contamination of Exercise Equipment. Clinical Journal of Sport Medicine, 16(1), 34-38. Available at: www.doi.org/10.1097/01.jsm.0000181436.41268.1f/.

Hirai, Y., Asahata-Tago, S., Ainoda, Y., Fujita, T., and Kikuchi, K. (2015). Edwardsiella tarda bacteremia. A rare but fatal water- and foodborne infection. Canadian Journal of Infectious Diseases and Medical Microbiology, 26 (6), 313-8. Available at: www.doi.org/10.1155/2015/702615

Holt, J. G. (1994). Bergey's Manual of Determinative Bacteriology (9th ed.). Philadelphia, PA. Lippincott Williams \& Wilkings Publishing.

Hyde, P. and Geiger, B. (2018). Bodybuilding.com: 10 Best chest exercises for building muscle, Retrieved from: www.bodybuilding.com/ content/10-best-chest-exercises-for-building- muscle.html.

Ibrahim, Z., Petrusan, A. J., Hooke, P., and Hinsa-Leasure, S. M. (2018). Reduction of bacterial burden by copper alloys on high-touch athletic center surfaces. American Journal of Infection Control, 46 (2), 197201. Available at: https://doi.org/10.1016/j.ajic.2017.08.028.

Kristich, C. J., Rice, L. B., and Arias, C. A. (2018). Enterococci, Enterococcal Infection - Treatment and Antibiotic Resistance. In: Gilmore, M. S.; Clewell, D. B.; Ike, Y.; and Shankar, N. editors. Enterococci: From Commensals to Leading Causes of Drug Resistant Infection. Boston: Massachusetts Eye and Ear Infirmary.

Mathur, P. (2011). Hand hygiene: back to the basics of infection control. Indian Journal of Medical Research, 134 (5), 611-20. Available at: www. doi.org/ 10.4103/0971- 5916.90985.

Mayo Foundation for Medical Education and Research (2018). Patient Care \& Health Information: Diseases and Conditions. Retrieved from: www.mayoclinic.org/diseases- conditions

Mukherjee, N., Dowd, S. E., Wise, A., Kedia, S., Vohra, V., and Banerjee, P. (2014). Diversity of Bacterial Communities of Fitness Center Surfaces in a U.S. Metropolitan Area. International Journal of Environmental Research and Public Health, 11 (12), 12544-12561. Available at: www. doi.org/10.3390/ijerph111212544.

Polat, G., Ugan, R. A., Cadirci, E., and Halici, Z. (2017). Sepsis and Septic Shock: Current Treatment Strategies and New Approaches. Eurasian Journal of Medicine, 49 (1), 53-58. Available at: www.doi.org/10.5152/ eurasianjmed.2017.17062.

Prevost, P. and Simms, D. (2020). Assessing the Antimicrobial Activity of Commercially Available Chemical Disinfectants Used to Kill Pathogenic Bacteria Found on Fitness Center Equipment. Unpublished data.

Rodriguez, M. (2019). Latest IHRSA Data: Over 6B Visits to 39,570 Gyms in 2018. The International Health, Racquet and Sportsclub Association. Retrieved from: www.ihrsa.org/about/media-center/press-releases/ latest-ihrsa-data-over-6b-visits-to-39-570-gyms-in-2018/.

Ryan, K., Ifantides, C., Bucciarelli, C., Saliba, H., Tuli, S., Black, E., and Thompson, L. (2011). Are gymnasium equipment surfaces a source of staphylococcal infections in the community? American Journal of Infection Control, 39 (2): 148. Available at: www.doi.org/10.1016/j. ajic.2010.06.006.

St. Clair Martin, J. and Chaney, L. (2007). Sports Etiquette. Proceedings of the 2007 Association for Business Communication Annual Convention, Association for Business Communication. Retrieved from: www. researchgate.net/publication/238734871_Sports_Etiquette.

Tacconelli, E., Carrar, E., Savoldi, A., Harbarth, S., Mendelson, M., Monnet, D. L., Pulcini, C., Kahlmeter, G., Kluytmans, J., Carmeli, Y., Ouellette, M., Outterson, K., Patel, J., Cavaleri, M., Cox, E. M., Houchens, C. R., Grayson, L., Hansen, P., Singh, N., Theuretzbacher, U., Magrini, N., and WHO Pathogens Priority List Working Group (2018). Discovery, research, and development of new antibiotics: the WHO priority list of antibiotic-resistant bacteria and tuberculosis. Infectious Diseases, 18 (3), 318-327. Available at: https://doi.org/10.1016/ S1473-3099(17)30753-3.

Vartoukian, S., Adamowska, A., Lawlor, M., Moazzez, R., Dewhirst, F., Wade, W. (2016). In Vitro Cultivation of 'Unculturable' Oral Bacteria, Facilitated by Community Culture and Media Supplementation with Siderophores. PLOS One, 11 (1). Available at: www.dio.org/e0146926.

Williams, C. and Davis, D. L. (2009). Methicillin-resistant Staphylococcus aureus fomite survival. Clinical Laboratory Science, 22 (1), 34-8. Retrieved from: http://hwmaint.clsjournal.ascls.org/. 